CHAPTER FIVE

\title{
THE ESTRANGEMENT OF ENGLISH CATHOLICS
}

\section{Constructing a Plain, Protestant and un-French Utopia}

The year that we take up the threads of the story, 1559, saw the publication of one of the defining political works of the Elizabethan reign, John Aylmer's An harborovve for faithfull and trevve subiectes against the late blowne blaste. Aylmer, a Marian exile newly returned from Zürich where he had helped John Foxe prepare the Latin version of the Acts and Monuments, threw himself into defending Elizabeth's God-given right to rule against the celebrated objections to feminine rule as raised by John Knox. ${ }^{1}$ This is the way An harborovve has been conventionally studied, but it also worth investigating what it has to say about post-Reformation identity. Commentators have often noted the importance of his statement to the effect that God Himself was English: it was the first explicit appropriation of the divinity to national ends and as such, the beginning of a more widespread complacency. Yet, that comment apart, it has not been realised just how deeply infused this treatise is with considerations of a national nature, and how important these are to the case he wants to make. ${ }^{2}$

Aylmer does helpfully give a definition of nature as 'a general disposition ingraft of God in all creatures, for the preservation of the whole'.$^{3}$ It is a conscious recall of Seneca. His musings on howe farre you stretche this vvorde nature' have been seen correctly in the light of what he has to say about feminine rule. Yet there is no reason why it cannot also apply to his endorsement of a natural English disposition which was manly, anti-Catholic, and anti-French. ${ }^{4}$ Aylmer's vision of Englishness is that of a promised (but endangered) land of plain, Protestant men immune to the attacks of 'our aduerseries' and 'sworn enemies' the Papists and, in particular, the blandishments of the papist French. ${ }^{5}$ Catholics are foreign by

\footnotetext{
1 Knox $155^{8}$ had actually targeted his work at Mary I, Mary of Guise and Mary of Hungary. Yet this was not how it came to be read. Elizabeth, who succeeded shortly after, took it as a personal affront.

2 [Aylmer] 1559, sig. $\mathrm{P}_{4}^{\mathrm{v}}$. This statement is actually to be found on the margins.

3 [Aylmer] 1559, sig. B4 ${ }^{\mathrm{r}}$.

4 [Aylmer] 1559, sig. Div

5 [Aylmer] 1559, sigs. $\mathrm{K}_{2}^{\mathrm{v}}, \mathrm{A}_{3}{ }^{\mathrm{v}}$.
} 
his own definition: a 'man in his own country at home, if he be not of the household of faith is a straunger' - an alien. ${ }^{6}$ The emphasis on France is understandable given the context of 1559. Mary Queen of Scots' marriage to the Dauphin in 1558 constituted the culmination of the Auld Alliance between Scotland and France. Her husband's sudden access to the French throne in 1559 as François II gave the English cause to fear for the future of the Reformation in Scotland, and by extension in England. Aylmer published An harborovve months before this accession. His anti-Popery is thus inseparable from a robust anti-Gallicism. Moreover, as we shall see, the possibility of a Papist royal marriage for the new Queen is something that makes him profoundly anxious. Accordingly, one of the main things that he is seeking to do is establish in his readers a national sense of themselves: a sense of distinctiveness and indeed superiority. He wants them to consider themselves in a position apart: in the consciousness of aloofness will rest their security from danger. He does this, first of all, by emphasising the providential blessedness of a state and people so constituted as they are. In a highly lyrical passage, he starts off by lamenting popular ignorance: 'Oh England, England, thou knowest not thine own welth' and he ends with the exhortation to bless God for having being 'born an English man, and not a french pezant, nor an Italyan, nor Almanac'. ${ }^{7}$

The blessedness consists in the enjoyment of a via media, which is composed of practical goods like the protection of a wise government, plentiful plainness, wholesome food and adequate clothing. Although it sounds a little anachronistic to say it, it does seem as if he is suggesting that being English means to live in a country which guarantees even the least of its members a decent standard of living. In contrast to the body of sources which set Italy up as a model of civilisation, he maintains emphatically that 'England is the paradise and not Italy, as they commonly call it.' Once again, he sighs over popular ignorance: 'Oh if thou knewest thou Englishe man in what welth thou liuest, and in how plentifull a Countrye'. He proceeds to highlight the national blessedness by contrast and mentions food (meat rather than vegetables), drink (beer and ale rather than water), and taxation (occasional rather than constant). His conclusion is that 'the Englishman' lives 'like a Lorde' whilst 'other countrymen', live pretty much 'like dogges', creatures rather than masters. ${ }^{8}$ Once again, questions of

6 [Aylmer] 1559, sig. L4v .

7 [Aylmer] 1559, sigs. $\mathrm{P}_{3}{ }^{\mathrm{r}}, \mathrm{P}_{4}{ }^{\mathrm{r}}$.

8 [Aylmer] 1559, sig. $\mathrm{P}_{3}^{\mathrm{v}}$. 
status were side-lined, as they often were, when the point was to create a sense of horizontal national bonding.

But when one wanted to demonise another nation, issues of status loomed large. It is the French extremes in society that are depicted: the 'fine-mouthed' courtier is sophistical and false whilst the miserable peasants are unpleasantly 'scraped to the bones'. ${ }^{9}$ The falseness of their social divisions are entirely of a piece with the falseness of their religion: he sees them as being the mainstay of the Pope and the Turk. They are Saracens in the very heart of Christendom. But, he insists, they cannot be monarchs of the world. Why not? It is because they are not manly and English: a naively simple point but that is the nature of such national propaganda. 'No good Englishe man they be effeminate French men: Stoute in bragge, but nothing in dede'. ${ }^{10}$ Then he proceeds to launch into a sketch of historic victories over France and laments that, through negligence rather than lack of manliness, they have not been able to maintain their Gallic hold. He has been careful to dismiss the Norman English past, saying categorically ' $[\mathrm{w}] \mathrm{e}$ be the Saxons posteritie' and is quick to relegate long-term Gallic influence to a residual few legal and hunting terms. Present-day 'language and customes' emanate entirely from the Saxons." This deliberate falsification of the past shows just how polemical his intents are. His point is that if one is to be thoroughly English, Saxonism is the only inheritance with which one can identify. ${ }^{12}$ He leaves his readers no option.

His denunciation of the French thus feeds into a construction of Englishness which becomes, in these rousing passages towards the end of the text, a full-blown 'exhortacion to manlines' through which he seeks to rally his compatriots into unity in the event of war. His vision of Englishness is not that of passively accepting the blessed state of being in which the munificent English God has placed them. Aylmer has particular expectations of how Englishmen should behave. His rallying cry is that his readers 'shew your selues true Englishe men' in the qualities of readiness, courage and boldness. They are also enjoined to fear neither the Frenchman nor the Scot (the Scots, in his view, are honorary Frenchmen because of their compulsive lying). He quotes approvingly a nobleman who proposed the halter for a tardy soldier, saying that 'whyte liuered mylke soppes be no

\footnotetext{
9 [Aylmer] 1559, sigs. $\mathrm{Q}_{3}^{\mathrm{r}}, \mathrm{P}_{3}{ }^{\mathrm{r}}$.

10 [Aylmer] 1559, sig. Q1 ${ }^{\mathrm{v}}$.

11 [Aylmer] 1559, sig. Q2 ${ }^{\mathrm{v}}$.

12 [Aylmer] 1559, sig. Q2v.
} 
true Englysh, for thei lacke [...] Englishe hartes'. ${ }^{13}$ He who could be relied upon to repel the Papist French was, for Aylmer, a key point of stability in this year of crisis, almost, it would seem, its guarantor. Indeed, his emphasis on the strength of native manhood seems to be his way of compensating for the necessary focus on the female monarch whose claims he is also anxious to support.

Already he is haunted by the shadowy figures of Elizabeth's future suitors, who may well be Catholic foreigners. This fear surfaces when he has to weigh up a common objection to feminine rule on the grounds that by her marriage, the realm is more likely to be 'transferred to straungers'. The succession of a single monarch would be followed in the normal course of events by a dynastically appropriate match, and thus the question of having a stranger as male consort was one that seemed likely to impinge soon again after the Marian marital fiasco of the 1550 . Given his strong convictions about the native 'ornamentes of a home-borne man', his preference would always be for a domestic alliance: 'better ioignynge at home, then chusing abrode'. Nevertheless, his one concession for a German prince 'or some such other' is revelatory. He conceives of them as active and religious men, without ambitious hearts, and not to be faulted for rigorous government. Moreover, there was a greater likelihood that they would be of the reformed faith.

Most importantly, such a one would not bring in 'hys own countrye men to oppresse the Subiectes (as vndoubtedly the Spanyardes and Frenche woulde)'. The belief that Catholic monarchs were oppressive (an inevitable corollary of an oppressive belief system) is something that will be explored more deeply by later writers, but the assumption is already being made here by Aylmer. The Spaniards and French are more foreign, as it were, than the Protestant Germans. To live as free, stout and thriving Englishmen under a Popish monarch was unfeasible. ${ }^{14}$ Another significant aspect of his indirect advice to the Queen is how little it concerns itself with dynastic considerations and how much more it is concerned with the fate of ordinary Englishmen. This again is a theme that we shall see taken up in later polemic. There is a discomfort with the fact that the monarchy pursues its own agenda which just may be repugnant to the emergingly self-conscious populace. Thus, the work intended to proclaim loyalty to the new Elizabethan regime is not confident about the direction in which that regime might go. There is unease clearly evident throughout. In the

${ }_{13}$ [Aylmer] 1559, sigs. $\mathrm{P}^{\mathrm{v}}, \mathrm{Q}_{3}{ }^{\mathrm{r}}$.
14 Aylmer] 1559, sigs. $\mathrm{L}_{3}^{\mathrm{r}}, \mathrm{L}_{4}{ }^{\mathrm{r}}$. 
work's peroration, he enjoins his fellow countrymen to '[b]e no slaues wher you haue bene Lordes', nor 'subiectes, where you haue bene rulers'. ${ }^{15}$ It is a robust imperative to resist foreign encroachments, however high-up they might enter. Most revealingly of all for the emergent language of communal selfhood is the phrase: 'Let no straunger make you straungers to your selues'. ${ }^{16}$ In fact, Aylmer's whole thinking on matters of identity could be summed up in a commentary on this passage. He could be said to have elaborated on the process of estrangement. Catholicism, after all, was so very recently English: rooted and grounded for centuries in national life. In the generations succeeding the Reformation, it was the task of polemicists to make it seem strange, alien and un-English, to show it as standing for a range of qualities and attributes which were incompatible with national character. It would be all the easier to do because their significant political enemies happened to be Catholic. Both antipathies came together and fed off each other. Aylmer is thus one of the first of the Elizabethans who seek to make readers see and interpret distinctions between cultures through the prism of religious difference.

It was not royal marriage but the recent rising of the Northern earls that played on Thomas Norton's mind in 1569 , causing him to publish $A$ warning agaynst the dangerous practises of papistes, and specially the parteners of the late rebellion. Lake and Pincus see Norton as somebody who helps frame the 'post-Reformation public sphere. ${ }^{17} \mathrm{He}$ was one of a rash of parliamentarians breaking out into pamphleteering and seeking to mobilise opinion beyond the privacy of the chamber. Although this work is conventional to the extent that it cries treason and proclaims divine deliverance after one of the more serious incidences of rebellion in the reign, it escapes its own generic conventions by its explicit statements on the un-Englishness of all Papists. The text functions on several levels: as a warning against Papists, as an indictment of their contradictory position and also as an appeal to them to convert. There is an equivalence between 'all true Christians' and 'all true Englishe subiectes', and papists can be 'neither true Christian men nor true English men'. He goes as far as urging them to 'come home'. 18

15 [Aylmer] 1559, sigs. $\mathrm{R}^{\mathrm{r}}-\mathrm{R}_{2} \mathrm{v}$.

16 [Aylmer] 1559, sig. R2 ${ }^{\mathrm{v}}$.

17 Lake and Pincus 2007, p. 4.

18 Norton 1569, sig. Oiiiv. The rising itself was instigated by Norfolk, who had been prevented from marrying Mary Queen of Scots. He had pulled out of the plans, but the Catholic Earls of Westmorland and Northumberland marched south to rescue Mary. It was a drab unsuccessful affair with serious repercussions. Hundreds were punished by hanging in its wake. It was in the immediate aftermath that Pope Pius V published the Bull of excommunication against Elizabeth. 
Probing the text further to see why it is that Papists cannot be true Englishmen in Norton's eyes, it is possible to advance three main reasons. Firstly, it is because Papists are not content to liue in bond of countrey with English men alone': they have eyes perpetually fixed abroad and are always too willing to 'join' with strangers, 'submit' to a foreign potentate. This is straightforward enough and need not detain us. Secondly, and more profoundly, it is not just the fact but the nature of their subjection that is problematic. It is possible to say that Norton has two models of subjecthood in mind. One is proper and fitting for an Englishman: it consists in lawful allegiance to a native monarch; emotionally, it gives one a focus for one's 'naturall affections'. ${ }^{19}$ The kind of subjection extracted by Rome is of a different order because it draws men into 'slauishe subiection', but since one cannot be a slave and English, one cannot therefore be of the Roman Catholic faith. Instead of directing one's natural affections, it was a channel for one's unnatural and outlandish ones, resulting in subversive plots and rebellion.

Norton goes deep into the motivations behind the recent rising and what it says about the rebels. Crucially, he does not regard them as free agents, but as tools in the hands of a foreign potentate. ${ }^{20}$ Fortuitously, according to Norton, the rising failed. The motif of providential deliverance is an habitual trope of the period, and as such, not one that generally stands out in its individual occurrences, but it takes on extra meaning in Norton's $A$ warning once we grasp just what he thought they were being delivered from: an unfree system that would crush the Englishman qua Englishman. This is the sense behind the opening passage in which he extols Elizabeth for saving them from 'foreine thraldome of soules, the escape of the heavie yoke of strange dominion'. ${ }^{21}$ The Roman yoke as well as the Norman yoke was to become a meta-trope of the polemic of the period. Religion forms part of the rich layer of resistance to foreign slavery that we shall see in political form in a later chapter.

The third reason why Papists are no true Englishmen is because they are innately duplicitous. They deck out disloyalty with rhetoric, with pretensions of legality. They cloak their actions, or, in his words 'colour foren subiections of our countrey with false titles of wrested law'. ${ }^{22}$ The idea of 'colouring' one's actions is an especially striking one and it takes us back to the anti-rhetorical postures of other Elizabethan writers. It shows the

\footnotetext{
19 Norton 1569 , sig. Jiir.

20 Norton 1569 , sig. Dijv.

21 Norton 1569, sig. Aiir ${ }^{r}$.

22 Norton 1569, sigs. Oiiiv, J iiv.
} 
way in which Catholics are coming to be portrayed as essentially rhetorical (coloured, cosmetic, distorted) creatures whose very sophistication (linguistic, liturgical, or theological) is a falsity. The notion of the foreignness of their make-believe and of performance is further brought out by the analogy of the playhouse: 'to play the good plaine Papist [...] is to play or rather in good earnest to be a hye traitor'. ${ }^{23}$ If you are playing a part that is not your own, then you are falsifying: you are not representing yourself. If one is a plain man, one does not 'play parts', cannot indeed. The idea of Papists playing a false part on an English stage, and putting on an alien 'persona' or mask will be a recurrent one throughout this way of thinking and it reflects the ambivalence towards the theatre particularly in these decades when it was growing in popularity. Theatre was taken by many to be a 'socially as well as a morally and religiously disruptive force' and its metaphoric usefulness as a way of stigmatising Popery was obvious. ${ }^{24}$

The Elizabethan controversies surrounding religion and identity could themselves be said to have become a theatre in which two different and potentially conflicting logics frequently pulled against each other: the dynastic and the national. This is a germane issue. One of the great discomfiting facts facing Protestant writers of the day was that royalty itself was transnational. Its dynastic and diplomatic needs might be expected to transcend, and at times, violate national bonds: a case of nice customs curtseying to great kings. ${ }^{25}$ After the Marian period, this was seen as increasingly problematic. In particular, the prospect of a royal marriage to a European Catholic spelt disaster. Accordingly, the sources are shrill in their assertion that the national should trump the dynastic every time and in making this case, they also seek to build a fulsome case of incompatibility. This is especially notable in John Stubbes' The Discouerie of a Gaping Gvlf wherein England is like to be swallowed, a text which show-cases antiCatholic and anti-French polemic as it stood in 1579. Two decades had elapsed since Aylmer had written, and a Catholic royal marriage, which then had been only a possibility, appeared now as an imminent reality of calamitous proportions in the advancing and seemingly favoured suit of François, who had recently acceded to the dukedom of Anjou.

The courtships of Elizabeth by himself and his elder brother Henri had dominated the decade. Diplomatically, some such arrangement seemed to make sense: England needed to consider a French alliance as a bulwark

23 Norton 1569, sigs. Bjr ${ }^{r}$ Oiiir ${ }^{r}$, Fiiir .

24 Lake and Questier 2002, p. 455.

25 Shakespeare Henry V 5.ii. 
against Spanish might. Although the proposed marriage to the brother of the French King had its supporters because of this, notably among the principals themselves and Lord Burghley, it nevertheless awoke such fierce opposition that it never came off. That in itself is a point of interest. What power did public opinion have? Clearly, more than is sometimes imagined. The Discovery was a crucial intervention in this controversy. The notoriety of some of its language as well as the vicious official reaction make it one of the best-known of the publishing controversies of the age. ${ }^{26}$ Present, in fact, are the same fundamental considerations that characterised An harborovve, namely the establishment of the Englishman as somebody who cannot and will not stomach the dynastic manoeuvres which might bring him under the sway of the Papist French, thereby submerging his values, and alienating all that he is and ever has been.

In fact, even more so than with previous texts, he brings out the connection between models of dependency and the Catholic French. This fed into his positive vision of the sturdy Englishman whose plainness of speech I have already had occasion to note. ${ }^{27}$ Stubbes presents the sensationalist possibility of a mass migration of miserably poor as well as Papist Frenchmen into England.

$[\mathrm{M}]$ ore danger vvil theyr be, least these needie spent Frenchmen of Monsieurs traine, being of contrary religion and who are the scome of the Kings Court, which is the scome of all France, which is the scomme of Europe, vvhen they seeke, like horseleaches, by sucking vpon vs to fill theyr beggarly purses to the satisfieng of theyr bottomlesse expense: the poore playne and rude Englishman first giue him the elbovve in the streete, then the fist and so proceeding to farther bicquerings. ${ }^{28}$

What emerges is the familiar polarised portrait of two national types: the typical Frenchman is seen as the very scum of life, at the bottom of every rung, while the ordinary Englishman is a healthy, sturdy specimen, as different from subservient suivants as it was possible to be. So far, so commonplace.

Yet there is more to be to probe in his remarks. Insofar as this English type is poor, his poverty is nonetheless of a different order to that of the parasitic misery of his French counterpart. He almost seems to be endowed with an honest Christian poverty; something of an ideal for one of such religious sympathies for he had known Puritan leanings. The allusion to

\footnotetext{
26 Vanhoutte 1996, pp. 49-77 has written on the gendered aspect of the pamphlet.

27 See above pp. 43-45.

28 [Stubbes] 1579, sigs. C6 ${ }^{\mathrm{r}}-\mathrm{C} 6^{\mathrm{v}}$.
} 
his rudeness of manner is also of interest, as this is not a sentimental kind of patriotism. Instead, he makes a virtue out of something we are at first inclined to think not a virtue. The Englishman is sturdy, if unrefined, and curiously self-contained: he does not know the finer things of life, but neither does he strive after them. This is a sort of John Bull avant la lettre. If the archetype was not wealthy or cultured, neither was he a model of tact, something that Stubbes continues to construe in a wholly positive way. That this man will not take the change passively is a tribute in fact to his sincerity of heart; he is not naturally belligerent, but in no circumstances could he stomach being 'a minion of Monsieurs'. One senses in this the authorial curl of the lip. The very word minion was French in origins, and its louche connotations would not have been missed. As well as being an unimportant henchman, it also carried connotations of homosexuality from the fifteenth century onwards and indeed that was an accusation commonly made against French courtiers, another proof given of their lack of manliness. ${ }^{29}$ Once provoked, the Englishman's reaction is likely to be quite direct and the allusion to bickering suggest that there may be conflict on the streets. Stubbes is adamant that the response to migration will be a raw, even bloody one.

Even the lightest allusions in such a passage open up avenues of thought, and although Stubbes is undoubtedly building on old prejudices about the French, hoarded in the common mind for centuries, here they are given particular direction and focus. While the Englishman was simply poor, the Frenchman is needy and worn - already the emphasis is on the insufficient and insatiable quality of his poverty, and this despite the fact that he would technically be of the 'victorious' party. Moreover, while the Englishman was pictured as an individual who stands alone, the Frenchmen were members of a 'train', followers in other words, not men in their own right. In fact, although they may be called a train, they seem more like an unruly mob. He also develops at this point the idiom of dependency by picturing the French as, at various points, sucking, clinging, and gathering: all actions associated with the infantile or the effeminate, and clearly at odds with the Englishman's gestures. Even their manners of wooing a lady is different. The Duke's methods of courting Elizabeth 'makes vs in England to find very strange, this vnmanlike, vnprincelike, secrete, fearful, suspitious, disdainful, needy french kind of woeng in Monsieur'. Stubbes raids history and finds the model he wishes in the bluff courtship of Henry V. His manner was plain and open, when he went about securing a French wife,

29 [Stubbes] 1579, sig. D $5^{\mathrm{r}}$. OED sub minion, 1. 
Catherine de Valois, a common belief echoed by Shakespeare's play twenty years after this text. According to Stubbes, he gave 'shew of vvisdome, manhod, behauiour, and personage' not to speak of the fact that his conversation was 'open' and the variety of his 'knightly excercises' highly various and impressive. ${ }^{30}$ Both high up and low down in society, distinctive characteristics separate nation from nation.

Animating all these socio-cultural antipathies are religious factors. This is evident in many ways. Although Anglo-Gallic 'inbred hatred' had a long history, and although some of it is transgenerational, having been instilled, he says, by grandfathers, who in teaching their grandsons to shoot 'wold haue them imagen a Frenchman for theyr butt', there is something fiercer about the prejudice in 1579 as he formulates it. ${ }^{31}$ This is a generation living out the Protestant reformation. To old hatreds are added new ones; to antique reasons for animosity are added fresh and even more compelling ones. Notably, although he resists the incoming of the French in general, he makes an exception for Huguenot émigrés who have been coming into England since the St Bartholomew's Day Massacre in 1572. These he welcomes, saying that 'our old grudging nature against the French in this respect, is expelled'. 32 They are the right sort of migrants apparently: their religion is compatible with Englishness.

The key to his thinking on this matter is a passage in which he expands upon what he understands by 'the soule of Fraunce'. ${ }^{33}$ He finds that the spiritual quality which defines it is servitude. Unlike the Englishman who is simply subject to one earthly power, and retains freedom within that, a complex chain of subjection binds all Frenchmen. This is replicated at more elevated echelons: high-ranking nobles are all beholden to the infamous Catherine de Medici, the Machiavellian female personified. In a strikingly sinister image of her hegemony, he described her as the 'very soule whereby the bodies of the King, of Monsieur, of theyr sister Marguerit, and of al the great ones in Fraunce do moue as a hundred hands to effect hyr purposes'. His Catherine appears as a puppet master and again the notion of play and manipulation are brought into sharp focus. Yet the skeins of subjection do not end even with her, because she in turn is to be considered but as a 'bodye or tronk wherein the Pope moueth, as hys soule'. ${ }^{34}$ In short, Stubbes felt that, if one excavated deeply

\footnotetext{
30 [Stubbes] 1579, sig. $\mathrm{F}_{4} \mathrm{v}$.

31 [Stubbes] 1579, sig. C2 ${ }^{\mathrm{r}}$.

32 [Stubbes] 1579, sig. C6 ${ }^{\mathrm{v}}$.

33 [Stubbes] 1579, sig. B4v".

34 [Stubbes] 1579 , sigs. $\mathrm{B}_{4}^{\mathrm{r}}-\mathrm{B}_{4}{ }^{\mathrm{v}}$.
} 
enough into the dispositions of the French, one would find that subjection to Rome was their essence. The 'Italian Quintessence of mischief was capable of imposing his will on 'hys catholike [...] sonnes', they being merely the executors, 'obedient fooles [who] doe hys will'. ${ }^{35}$ Ultimately this is what Stubbes wants to point out as the most deeply problematic element about unifying the countries through a Catholic match. The question was whether the English were to be caught up in this complex chain of subjection, having no will to call their own? Was their very soul to be put at risk? Were they ultimately to be dependent on the arbitrary will of the Court of Rome? This theme of arbitrary power and subjection will become in several decades a heavily political discourse: the idiom is already taking shape in anti-Catholic polemic as it had done in cultural domains.

There is a further worry in the particular context of 1579 , and indeed throughout the Elizabethan period. This is because there is a deeply gendered dimension to the notion of subjection which in turn will problematize the default identification between masculinity and nationhood. Stubbes' point seems to be that subjection and therefore servility will be all the more acute because it involves the marriage of an English woman to a Frenchman. In other words, England was being married - given away, as it were, - to France rather than the other way round. In the past, the English remained English, because change came recognisably in the form of a male conquest, not a feminine submission. He conveniently ignores the Normans in his narrative. The kings went to France to be 'maisters of countrey and people' - naturally, so he thinks, because they were English. Being male, there was no loss of identity: 'vvheresoeuer theyr king vvent he was styll an Englishman'. What he is saying is that the King is an Englishman first and a king second and that it is in the former capacity that he can claim mastery, and in the latter that he does. It is still, we note en passant, a curiously class-transcendent vision. If the present Queen marries abroad, she was putting Englishmen - the rough plain types that we have seen earlier - in the untenable position of women, something that is wholly repugnant to who they are. He shudders at the thought that 'both she and we poore soules, are to be mastered and, vvhich is vvorse, mistrised to'. 36

It was for all these reasons that the prospective marriage to the Duke was repulsive to 'euery English hart'. ${ }^{37}$ Throughout the text, Stubbes harps

35 [Stubbes] 1579, sig. B6r .

36 [Stubbes] 1579, sig. $\mathrm{D}_{3}^{\mathrm{v}}$.

37 [Stubbes] 1579, sig. A2 ${ }^{\mathrm{v}}$. 
upon the importance of this; if there is a foreign royal, the law will see to it that as an alien, he is disabled from exercising full government because the legal presumption is that he will be a 'senceles and careless forreiner' lacking in an 'English hart'. ${ }^{38}$ Whether, for Stubbes, English Papists are at all 'true' is a moot point. His grudging conviction that any papist 'that hath an Englysh hart left to knok vpon in his breast, wyllbe afrayde to call Monsieur his mayster' is not to be construed as a conviction that there actually are any such to be found. ${ }^{39}$ It is a challenge for them to put their national ahead of their supranational identity and transnational territorial affiliations.

Is Stubbes pessimistic or optimistic about the direction England is taking? In one sense, the text is riddled with anxieties. Speaking of those advocating the match, he has this to say.

And if these men vvere eyther regenerate with theyr lyuing brethren by the Gospel, or yf they were not degenerate from theyr deceased noble fathers, and remained but in theyr pure naturalles, they would neuer so speak for a faultor [offending] prince of Rome, and one that may be warranted to vs and our heyres for an enemy auncestrell. ${ }^{40}$

All that is needed to be a loyal son of the nation is to maintain one's 'pure natural' state of being in the way that he has construed it in the text, but these men are clearly degenerate. Already also, there were signs that elite Englishmen were losing their proper dispositions in cultural ways, and throwing their lot in with France. This nicely parallels the socio-cultural preoccupations of contemporary satires. In the past, he nostalgically recalls, they 'delighted rather to be seene in Fraunce in bright armour then in gay clothes and masking attire', and that 'they did chuse rather to vvin and hold by manly force, then by such effeminate meanes' ${ }^{41}$ It was no longer so. The question is whether the fight is being lost off the battlefield, in the more insidiously dangerous world of the court. Still, he has some confidence in the toughness and resilience of English nature.

But against these irreligious, haughtye and faithlesse frenchmen, that bring in a religion contrarye to ours, and haue no conscience nor loue to vse vs kindly, our English nature vvil return a main [sic.] to his own course. ${ }^{42}$

The statement that 'English nature' has sufficient power to redirect man to his proper ends is intriguing evidence of Stubbes' belief in an

\footnotetext{
38 [Stubbes] 1579, sig. B8v.

39 [Stubbes] 1579, sig. $\mathrm{C}_{3}{ }^{\mathrm{r}}$.

40 [Stubbes] 1579, sig. $\mathrm{D}_{4}^{\mathrm{r}}$.

41 [Stubbes] 1579, sig. ${ }_{3}{ }^{\mathrm{r}}$.

42 [Stubbes] 1579, sig. C6 ${ }^{\mathrm{v}}$.
} 
autonomous communal self which is capable of being an agent of reform and purification in dangerous times. Ideas about identity are maturing.

Stubbes, seeking to make a popular pitch, had a thousand copies of this text printed and distributed in August 1579 but soon found them banned by a royal proclamation. Arrested and found guilty of felony, he had his right hand amputated. What are we to make of such an episode in the light of the text? Stubbes' intervention creates a composite case against a Popish match by deploying a full range of arguments based on identity and counter-identity. Elizabeth saw it primarily as a work of protest and felt herself threatened. Indeed, there was a certain (unintended?) subversiveness to the populist pitch he was making. It could be said that, in his hands, the construct of the plain non-papist Englishman came to the fore not merely as a point of reference but as a moral judge in his own right, engaging in 'affairs of state' traditionally seen as being beyond him. In the real world, he may be considered a cog in the diplomatic machine but in the racier and less exclusionary world of the print media, his is the voice that emerges uncorrupted, the one who cannot stomach the idea of French Catholic infiltration at any level and is not afraid to say as much. Stubbes is an important player in transferring private political discussions that would have taken place within parliament into the public domain, calling into being 'an adjudicating public or publics able to determine the truth of the matter at hand. ${ }^{43}$ Stubbes' Englishman had declared himself.

\section{The Alienation of the Jesuits}

A new emphasis emerged in the last two decades of the sixteenth century which insisted that popery represented cosmopolitanism and rootlessness as against the stability required for the true Englishman. In the discourse surrounding plainness, we have had occasion to analyse the discomfort with the re-integration of the traveller; here the animus was particularly directed against the mobile figure of the Jesuit. The new emphasis is, contextually, unsurprising. The arrival of a Jesuit mission into England in 1580 brought the country into contact with a new phenomenon of religious peripatetic, 'English' by birth, continental by training. It was unsettling on every reckoning. The Society of Jesus, approved by the pope a mere 40 years previously, represented the avant-garde of the Counter Reformation, consisting of committed, often brilliant clerics,

43 Lake and Pincus 2007, p. 6. 
educated homogenously, and under vows of obedience to their Superior General in a way that made them, according to Ignatius, their founder, disciplined 'like a corpse'. Above all, they were mobile as no other order had quite been before: organised as a military company, they were sent all over the world on missions. That factor alone would have made them intimidating to many people who had not travelled beyond their native land.

Their coming gave a new focus for ideas about the foreignness of Roman Catholicism, and it provoked a range of official and unofficial reactions of note. ${ }^{44} \mathrm{Of}$ the first, the royal proclamations of 1580 and the legislation of 1581 stand out, as does the execution of the leader of the mission, Edmund Campion and two companions in 1581, a deterrent against further attempts in the same line. ${ }^{45}$ Of the second, the hostile printed responses were most characteristic, raising accusations of disloyalty, sedition, and treason, and this, despite the fact that Campion and his fellows had brought a breve from the then Pope, Gregory XIII suspending the effects of Regnans in Excelsis indefinitely. But no Jesuit mission stood a chance of being regarded as merely spiritual, whatever their protestations. Nor, as Lake and Questier have pointed out, would the threat be regarded as 'merely political in the narrow invasion-, plot- and sedition-centred sense of the term.' Fundamentally, it was an ideological matter and that is where the discourse of identity plays a central role. ${ }^{46}$

It is in Meredith Hanmer's interjections that we find a typical response of the insecure Protestant nation, when confronted with a fresh Catholic presence, heavily engaged in illegal printing and preaching. Hanmer was a beneficed clergyman, making his first sortie into print, which accounts perhaps for the rough quality but also the vividness of both The Iesuites Banner and The great bragge and challenge of M. Champion a Iesuite. The second came in response to the Jesuit's list of points, addressed to the Privy Council, in which he challenged councillors, scholars and lawyers to a disputation on religion. ${ }^{47}$ It is principally from Hanmer's treatment of Campion, whom he claims to have known at Oxford, that the first real

\footnotetext{
44 For details of the Society's membership and activities in England see Edwards 1981; McCoog 1994-5; McCoog 1996.

45 On the matter of this legislation see Neale 1953, vol. 2, pp. 386-92.

46 Lake and Questier 2002, p. 261.

47 As Campion's Challenge was merely written and distributed in multiple copies by Thomas Pound, the only 'copy' that was printed was in Hanmer 1581b. He interspersed it with his own refutation. Since then, it has been printed entire in Reynolds 1982, pp. 78-81. This is the text I have used.
} 
articulation emerges of the 'oxymoronic' concept of an English Jesuit. ${ }^{48}$ Campion was the most worrying phenomenon of all. He was undeniably an Englishman with impeccable educational credentials: his influence at Oxford had been so significant that his students took to copying his way of speaking. He was, furthermore, chosen to give the oration during the Queen's visit and had enjoyed the patronage of the Earl of Leicester. Yet, he had done the unthinkable and turned 'traitor' to all this, leaving the country in the 1570 s to train to become a Jesuit priest. Hanmer makes an urgent appeal to this enfant terrible on the grounds of nationality: 'You are an Englishman borne,' he tells Campion 'God hath endued you with sundry good giftes, let not your nature be estraunged' ${ }^{49}$ By 'estraunged', he was, in effect, saying that Campion was rendered alien, was severed from the community. This idiom is a very common one: a few later, William Lightfoot will complain that the Jesuits and priests 'estrange your selues' ${ }^{50}$ Romanism is not merely an aberration, but an utter alienation. The man who was once a fine representative of all that was best in elite English life has become a national menace: all the 'brethren and countrey men' are to be warned against such a one. ${ }^{51}$

Hanmer's text is a good example of what one has to do to 'deconstruct' somebody's reputation among the educated classes. To ask how deeply Hanmer's thinking goes as regards the alienness of the Jesuits is to uncover the meaning of his remarks about both travel and slavery. It must be emphasized again, in explanation of the first, that the Jesuits were the supreme cosmopolites of the Counter-Reformation, setting up in various locations with a speed and efficiency which set them apart from the older Catholic mendicant orders. Their use of a clandestine press at Stonor Park, Henley within months of the start of their mission was some indication of what might follow. They were immensely mobile and efficiently adept at exploiting networks of communication and transport. For Hanmer, this peripateticism smacked of rootlessness, discontent and mischief-making on an international scale, qualities suggested by his image of them as 'Wandering Romanistes' ranging abroad and his plea to them to renounce all 'Popish pylgrimages, and wearisome iournies'. ${ }^{52}$ Hanmer did not want

48 It is possible that he did. Campion was in Oxford for 12 years from 1558 to 1570 ; Hanmer went up in the late 1560 s to be a chaplain and was still only graduating with a B.A. in 1568 , when Campion attained the prestigious position of a junior proctor. ODNB.

49 Hanmer $1581 \mathrm{a}$, sig. $\mathrm{C1}^{\mathrm{v}}$.

50 Lightfoot 1587 , sig. $\mathrm{C}_{2}{ }^{\mathrm{r}}$.

51 Hanmer 1581 b, fo. $3^{\mathrm{r}}$.

52 Hanmer $1581 \mathrm{a}$, gathering $3^{\mathrm{r}}$, sig. $\mathrm{C}^{\mathrm{v}}$. See also Hanmer $1581 \mathrm{~b}$, fo. $15^{\mathrm{r}}$. 
people to seek anything outside national borders, or bring home any strange disguising: he shows just the same discomfort with the practice as social satirists did. It is further brought into relief by his citation of the phrase in the very first few lines of the text: 'Stultus populus querit Romam,' a foolish people looks to Rome. ${ }^{53}$ Looking to Rome did not lend itself to building stable domestic identities.

The other troubling aspect of the Jesuits which affronted English nature, Hanmer would have the reader believe, was their subservience to a foreign power. Although this is familiar ground at some level, the Jesuits are even more implicated than the ordinary Catholic because of their extra layer of subservience to the head of their order. He attacks them for

your obedience and tyinge your selfe to that order and trade of life (beyng an Englishman) to a forrain and a straugner (whom yee call your Prouost) enemy to god, [...] a sworne aduersarye to our soueraygne Lady, the Queens maiestye the Crowne \& Dignity. ${ }^{54}$

He also refers to the Provost as a 'Controller' who dictated their movements. The very word reeked of negative preconceptions about the kind of allegiance that a Jesuit superior exacted from the individual. St Paul's injunction not to make 'your selues slaues vnto men' was quoted to support his case. ${ }^{55} \mathrm{He}$ even redescribed the phenomenon of joining the Society as a means of 'addict[ing]' oneself to a maimed soldier, a reference to Ignatius' first career before the foundation of the society. ${ }^{56}$ In the earlymodern sense of the term, to addict oneself meant to be attached by compulsion or obligation to a person. Both meanings are present here. There is compulsion: the suggestion that these men have been forced into joining the society through devious means. The obligation is constituted by the vows of obedience that members are required to take. Addiction also carried with it the connotation of immoderation and irrationality and thus is directly repugnant to the 'standard moral language' of moderation which characterised the prevalent discourse of the era. ${ }^{57}$

Seeing the Order through this lens, it is not surprising that Hanmer read the English mission itself as an insidious attempt to enslave. So even Campion's invocations of plainness in his Challenge were quickly

53 Hanmer 1581b, sig. A3 ${ }^{\mathrm{v}}$.

54 Hanmer 1581 b, fo. $8^{\mathrm{v}}$.

55 Hanmer 1581 b, fo. $9^{v}$. He references this as Corinthians 7 . A more likely source is Galatians 5.1. See also Colossians 2.8.

56 Hanmer 1581b, fo. $9^{v}$.

57 Shagan 2011, p. 3. 
deconstructed. In vain did the priest declare a 'plain confession' of the Roman Catholic cause, and advocate academic disputation on the religious question that would show how 'fair light [...] and plain dealing may be cast on these controversies' ${ }^{58}$ It is interesting, as an aside, that Campion should make much of the motif of plainness: it is a truth-claim, of course, but it also represents his desire to insist on a quality in which Jesuits are deemed to be particularly deficient. For Hanmer, there could be nothing plain about adherence to Rome and nothing would dislodge him from the belief that Campion and companions held something in reserve. In the very opening gambit, he declares that he 'would heare not a Romanist, but an Englishman speak'. He quickly attacks Campion's protestations of plain-dealing. Being a Romanist, he 'subtlely creepe[s] into the fauour of your Readers, by protesting an open show of plaine, sincere, and unfained dealing'. The Jesuits, in particular, are known to be subtle and therefore they cannot be trusted. ${ }^{59}$

He carries on deconstructing his opponent's case on stylistic grounds that are also, we know from other discourses, heavily imbued with national content. He refers to Campion's 'slye conueyaunce of Rhetorical insinuations' and warns his readers not to be carried away with his 'fayre shew and gloriouse flourish'. ${ }^{60} \mathrm{He}$ even criticises the manner of the dissemination of Campion's text which, instead of being published properly, was written and distributed in multiple copies by an associate. This was 'hucker mucker' practice according to his opponent, with the message received in 'scrowles and torne papers' ${ }^{61}$ Hanmer exploits the fact that it is he himself who has first 'printed' Campion's brags and put them in the open for the literate English to see. He has published the 'plain text' and then shown it to be an unplain text. 'Substance [...] I find not', but much 'bragging, and bosting'. ${ }^{62}$ This is, he would have us understand, in keeping with the whole bearing of the Society whose extravagantly humble gestures ('lowlye, dowking') are contradicted by interior pride and deceit. Nothing is as it seems with them. The hostility towards courtly gesture as already outlined is here imagined as Catholic gesture. After all, the centre of Catholicism was the curia, the court of Rome. Catholic gesture is thus perceived as courtly and it is disliked for similar reasons. All the bowing

\footnotetext{
58 Reynolds 1982, pp. 78, 79 .

59 Hanmer 1581 b, sig. $3_{3}{ }^{\mathrm{v}}$, fo. $2^{\mathrm{r}}$.

60 Hanmer 1581 b, fo. $2^{\mathrm{r}}$.

61 Hanmer $1581 \mathrm{~b}$, fo. $1^{\mathrm{v}}$.

62 Hanmer $1581 \mathrm{~b}$, fos. $2^{\mathrm{r}}, 20^{\mathrm{v}}$.
} 
and bending and kneeling are neither plain nor simple. Not merely are they overly-ritualised forms of expression but they are innately foreign.

Hanmer's theatricalisation of the Jesuits (and therefore their further alienation from national 'normative' ideals) is further brought out in his mystification that anybody, like Campion, who is 'willing to cast his head under every man's foote, and to kisse the ground they trade vpon, can play such pageants'. They are constantly playing roles and can, of course, drop the mask whenever they wish to reveal their false identity. He has urged Jesuits rather to strip off what is false and return to their native persona: 'cast of the Popes pelte', he tells them in the introduction, in short, shed the 'skin' of an inauthentic identity. ${ }^{63}$ Hanmer's pamphlets are extremely interesting examples of how, on many levels, a dichotomy is being hollowed out between the Englishman and the Jesuit-affected or indeed the Jesuit-addicted. The dichotomy is presented in multiple ways and depends in part upon other articulations of national identity taking place in more specifically cultural discourses. The fact that Hanmer constructs his texts as the plain-man's response to the crafty Jesuit is meant to be a reflection of what is happening on the ground in the battle for hearts and minds. His methods and his matter are at one. We should therefore be wary of dismissing his arguments as mere crude knockabout stuff. In a sense, there is much that is crudely simple about them - this is propaganda told with unholy relish - but there is also great strategic force and some subtlety. He strikingly uses resources from a wide variety of discourses (religious, political, and socio-cultural) to create the powerful image of the un-English Jesuit, exemplified in 1581 by the already-fated Edmund Campion.

\section{The Ideological Battle Against Spanishness}

It will have become clear by now that in the literature we are considering, anti-popery never came in pure form. It was commonly mediated by opposition to an intermediate Catholic power or religious order, just as it was commonly combined with whatever other issue - political, historical or cultural - to produce an even more potent case for its outlandishness. England's armed conflict with Spain from 1585 to 1604 meant that for much of the last twenty years of the sixteenth century and beyond, the true-hearted Englishman was construed not only in opposition to the

63 Hanmer 1581 b, fos. $20^{\mathrm{v}}$ sigs. $\mathrm{A}^{\mathrm{v}}{ }^{\mathrm{v}}, \mathrm{A}^{\mathrm{r}}$. 
Catholic Spanish themselves but to the Hispanicised at home. This appears with particular clarity in the year of the first Armada in 1588 and in the immediate aftermath of the third, a decade later. In contemporaneous texts, a rousing rhetoric of Englishness is freely used to work readers up about the fate of their nation and bring them, by means of a barrage of strategies, to the conclusion that one cannot be Popish and English at one and the same time.

In a pamphlet entitled $A$ briefe discouerie of Doctor Allens seditious drifts, written by one G.D., we get a good idea of how the events of the 158 os helped to cement a rhetoric of Englishness among the wider public. G.D.'s particular target was William Allen, the spiritual leader of exiled English Catholics and cardinal from 1587. He had exerted much pressure in the 1570 and 1580 s for the re-Catholicisation of England, and this enterprise had involved strategising for a French or Spanish invasion, and the replacement of Elizabeth with a Catholic monarch. By the 1580s, the matter was in the hands of Philip II, and Allen acted as something of an intermediary figure between Pope Sixtus V and Spain. These activities made him persona non grata in many circles and in this pamphlet, G.D. tried to undo the harm he had done in a published letter of 1587 which had spoken out against English support of the Calvinist Dutch rebels. ${ }^{64}$

Like Campion some time before, Allen had to be constructed as the anti-type of the true Englishman, actively seeking to subvert his patrimony. It was easily done. He was at once compared to Sinon, the subtle Greek, the character behind the false gift of the Trojan horse. ${ }^{65}$ His actions and arguments are depicted as the very reverse of 'plaine dealing' : with his 'subtill persuasions', he is innately double. All he utters is 'under a glosse'. ${ }^{66}$ Also in evidence is the language of enchantment as if Allen and his ilk use nefarious magical arts to woo people away from what is, for the author, the 'naturall loue of his country'. ${ }^{67}$ In response to this, G.D. makes the most of every opportunity to use the rhetoric of 'we Englishmen', and is much concerned that the whole country keeps 'true within it selfe', impregnable in the face of Romanist and Hispanic threats of any kind. ${ }^{68}$

Unsurprisingly, in an increasingly fraught international context, he constantly brings the motifs of manliness and nationality together.

\footnotetext{
64 Allen 1587.

65 G.D. 1588 , pp. $1-4$.

66 G.D. 1588, pp. 3-4, $\mathrm{A2}^{\mathrm{v}}$.

67 G.D. 1588 , p. 4 , A4v .

68 G.D. 1588 , pp. 123, 126.
} 
Referring to the threat, he asks 'shall wee be dismayed at it? that were not manlike. Shall Romish and Spanish forces appal vs? That were dishonourable for English men. ${ }^{69} \mathrm{He}$ also drums up the prospect of slavery, and this tactic of his is to be taken very seriously. Invasion would not just change a few structures in church and in political life: it would demean the nature of all. The question he poses is a loaded one: 'shall we be slaues in our own Countrie?' And he continues in the same vein: 'What an alteration (or rather degeneration) would this bee in vs? how dishonourable to the English name and Nation?' He goes on to state that freedom is bound up with the national story. Foreigners would fight merely for the sake of spoil but the English fight for 'lives and liberties'. He also harkens back to their glorious ancestors and hopes that this generation of Englishmen do not 'degenerate from the courage of our forefathers'. G.D. knew his audience: the argument ad antiquem was always a safe choice and was easy to assimilate. Still, his delusions of grandeur are rather transparent. He claims that if this generation fails to preserve themselves, they will be reproached by 'all other Nations' and 'succeeding Ages', in short, that they will become 'infamous Inhabitantes of so famous a Country'. ${ }^{70}$ Now this is purely his own construction: England was not an especially grand member amongst the European or indeed Eurasian powers in 1588 and its 'fall' would not have had the impact it is here said to have had. Yet, that very narrative with its largely 'mythical' invocation of historic greatness and international repute is an utterly crucial one to draw out. It adds something of transcendence to what otherwise might be quite a parochial story and it helped as they moved away from the lure of Rome to have an alternative macro-structure in its place.

Another feature to draw out of G.D.'s text is his emphasis on the heart, which is replicated again and again in other writings. There are two principal connotations attached to the idea, not only that of the heart as the source of the affections, but also as the seat of the will. By the one is suggested the affective aspect of being an Englishman, and by the other, the volitional - how the genuine Englishman willed certain actions and could be expected to do certain things and not others. As regards the orientation of their heart, the English Papists themselves held an extremely ambiguous position. Would they support an invasion? Where did the affections of their hearts truly lie? In that time of crisis, it was more necessary to examine their interior dispositions than to argue about their

\footnotetext{
69 G.D. 1588, pp. 123-124.

70 G.D. 1588, p. 124.
} 
religious practice and doctrine, although were it not for their religion, questions about their affective identities would not need to be asked. G.D. claims that he is not drawing them away from their beliefs per se. ${ }^{71} \mathrm{He}$ tries to hope that they will prove true but his phrasing expresses some doubt. 'Yet they are English men, and if they beare English hearts in their bodies, they will never endure a stranger [...] to tyrannise ouer their country': this looks very like an attempt to convince himself. It ought to follow, but the question is, does it?

He does try, unconvincingly, to reason out the case based on the English Catholics' enlightened self-interest. Even if they did bear malice towards the Queen, and abandon all calls of duty, piety, 'humanity, good nature, and manhood' in regard of their country, they must surely retain a measure of 'naturall loue' for 'their own liues, and liberties' which would prevent them taking on so dreadful a course as throwing in their lot with Spain. ${ }^{72}$ Underneath it all, there must be some core of Englishry. But he is merely fretfully rationalising. One could postulate that G.D. and others of his ilk in the second half of the Elizabethan period are obsessed with the question of security and of the future. What would Englishmen be within a generation? Would they be forced into playing other roles? In 1588, it was impossible to say and that makes the construction of national identity around hostile perceptions of Popery and its secular manifestations all the more urgent. A Briefe Discoverie is, in effect, a rallying cry in print, and its manner of making its case, just as much as the case itself, is of interest in the consolidation of this discourse. In the triad which constitutes the rhetorical culmination of the work, he urges that they link together in one mind, in one faith, in one force, let vs sticke togither, fight togither, die togither, like men, like Englishmen, like true-harted Englishmen'. ${ }^{73}$ The battle for the 'English heart' had begun.

\section{Debating National Authenticity}

It did not end there. The stories told around the time of the Armada have a privileged place in the construction of a national myth and the next place we take up the thread is with Sir Francis Hastings' A vvatch-word to all religious, and true hearted English-men, published twice in 1598, months after the third Armada was thwarted by autumnal storms. Profoundly

\footnotetext{
71 G.D. 1588 , p. 5 .

72 G.D. 1588 , p. 84 .

73 G.D. 1588 , p. 126 .
} 
interesting in itself in the way that it states its case, it is also important for launching a print controversy that lasted until 1604, attracting the attention of the Dean of Exeter, Matthew Sutcliffe and involving no less a person than Robert Persons, S.J. in opposition. Hastings and Sutcliffe were not particularly natural allies in many ways. Between them, there was not only an ungainly disparity in intellectual ability, but a great difference in theological standpoints, Hastings being on the more forward-pushing side of the Church of England, Sutcliffe the more firmly conservative. ${ }^{74}$ Yet, (and this indicates the centrality of the ideological binary between Catholics and Protestants), both these men felt that they could and should unite against the common enemy. One of the ways in which they found common cause was to base some of their arguments on the importance of having an authentic English identity, Hastings to a greater extent than Sutcliffe. ${ }^{75}$

Persons, drawn into the fray, was thus forced into a defensive position from the start, which he accepted with his usual instinct for controversy. He would show an extraordinary energy in pummelling and ridiculing the narrow nationally-focused arguments and lazy stereotypes; yet, as I shall argue, it was perhaps unfortunate, as far as his cause was concerned, that he made no significant attempt to appropriate their polemical idiom, adopting instead a uniformly critical stance to any 'measure' that involved appeals to or generalisations about national character. In dismissing his opponents in no uncertain terms, it was almost as if he had missed the opportunity to present a positive and populist case of his own which made Englishness and Catholicism compatible again. That the years immediately preceding the Gunpowder Plot and the Oath of Allegiance controversy would have been especially fitting for such a case only made his failure more consequential.

Hastings' voice was a parliamentary one, and by the time of his first sortie into print in 1598 , that of his maturity. ${ }^{76} \mathrm{~A}$ vvatch-word and its sequel, the Apologie or Defence of the Watch-Word, are best described as exhortations to vigilance and general national alert; the tone of both characterised by the insistence that all that was truly English was being jeopardised by Papists and popery. Hastings' basic societal division is between the

74 [Persons] 1599, p. 78 accuses Hastings of being a Puritan.

75 Hastings 1598; Hastings 16oo; Sutcliffe 16ooa; Sutcliffe 16oob.

76 Born in 1546, he had played no small role in the parliaments of the 1570 s and was 52 when he came to write $A$ Watch-Word. That he was a knight is made much of by Persons who speaks scathingly of his lack of moderation and civil virtues. See, for example, [Persons] 1602, p. 6. 
'true' and 'false' hearted Englishmen. He proceeds to give quite fulsome descriptions of each, covering their affections, will and nature of their actions. Before anything, however, this division is a convenient rhetorical device, used to suborn a readership. His claim to true Englishness is his way of justifying all his opinions. Towards the end of the Apologie, he put it to his readers as to a jury whether they would trust the views of his opponent, 'a Iesuiticall scholler and sworne Spanish' or himself, 'a Christian and true hearted Englishman'. ${ }^{77}$ By presenting himself as the very epitome of nationhood, he meant to win their trust entirely. There was no more disingenuous ingenuousness than this. With this ploy, he also sought to create unanimity both in the way his text was read, and also in the way every issue was to be judged, just as a later generation would do in the 1640 s. $^{78}$ When talking about William Allen, for instance, he appealed over the heads of divisive members to 'all true hearted Englishmen' to tell him whether or not he was an 'impudent [...] lyer' ${ }^{79} \mathrm{By}$ virtue of their being English, the unwritten sub-text ran, they could only decide one way.

What Hastings is especially successful at doing is building up emotional identification with the national cause. True English hearts will have felt the emotions of 'griefe and feare' at the danger to Elizabeth. ${ }^{80}$ Their affection was meant to converge on three realities, namely God, Queen and country. They were, in his neat turn of phrase, to fear the first, obey the second and love the third, as they were 'faithfull Christians, loyall suiects, and true-hearted English-men'. ${ }^{81}$ In itself, there was nothing particularly new about the formulation, except the emphasis on the last. The language of self-preservation was understandable because if England was Romanised or Hispanicised, this is precisely what they stood to lose. Hastings is also very keen to build up the civic consequences of having a true heart, to inculcate an active sense of duty in 'every true Englishman'. If $A$ vvatch-word does fall short of a call to arms, it still resonates as a call to greater civic participation. Because of this, it is not merely those who abuse England whom he singles out for blame, it is also those who do not do their utmost in her defence against 'Rome and Spayne', those, in other words, who remain passive in the face of the contemporary situation. ${ }^{82}$

\footnotetext{
77 Hastings 1600, p. 203.

78 See below pp. $23^{2-3}$.

79 Hastings 1598 , p. 47.

80 Hastings 1600 , p. 68.

81 Hastings 1598 , p. 84. See also pp. 69, 72.

82 Hastings 1598 , pp. $3,103$.
} 
A 'readie hand' is inseparable in his eyes from a 'couragious heart'. Or again, what he calls 'Neutralitie' is not fit for those who call themselves English. ${ }^{83}$ It is important to take sides, declare one's colours. His version of national identity is a politically and militarily-engaged one. In evidence also is the idea that the Englishman stands not merely for his country and ruler but for himself: as he says 'euen for the life, and liberties of our selves'. ${ }^{84}$

His depiction of the false-hearted or as he dramatically calls them the 'hollow hearted' English is also worth drawing out. ${ }^{85}$ Does he include all Catholics in this bracket? It is true that he does make allowance, in his 1600 work, for any ignorant Catholics who are free from subscribing to Rome's 'disloyal doctrine', and claims that he is 'farre from imputing the crime of sedition to all Recusantes'. For the rest, he spoke of the Papists, not just the plotters among them, in ways that broadly problematized even crippled - their national credibility. '[V]erie manie' have been 'ouertaken with this humour, by the perswasions of Iesuites' ${ }^{86} \mathrm{He}$ is not somebody who habitually bears in mind the niceties of distinction. Papists are problematic because they might well be passive in the face of invasion, or might indeed act against the instincts of their compatriots. The active, civically conscientious Englishman who stands for his liberties has given away to the agent for foreign powers who acts but not in his own right; that is to say his activities are regulated and constrained. Hastings' hollowhearted Englishmen are represented as having no will of their own: they are puppets. His comment on their thraldom signals this and there is a telling instance in which he labels Jesuits as 'agents for the King of Spaine' ${ }^{87}$ There is a distinction, he is implying, between free action and mere agency. The one is independent; the other controlled and pre-determined. This angle is of interest in the evolving rhetoric of freedom, articulated first in these politico-religious contexts.

Paralleling his emphasis on the affective affiliations of the Englishman, he also draws out what is perverted about the affections of Papists. Affectively, these 'home traitors' were defective, setting their hearts on Rome and Spain rather than on their native country. ${ }^{88}$ How one was 'affected' meant the way one was leaning. On that point, Mary Queen of Scots was, he claims, so

83 Hastings 160o, Preface (unpaginated); Hastings 1598, p. 103.

84 Hastings 1598 , pp. 69-70.

85 Hastings 1598 , p. 109 .

86 Hastings 160o, sig. A2 ${ }^{\mathrm{v}}$, p. 171.

87 Hastings 1598, p. 20; Hastings 1600, p. 196.

88 Hastings 1598, pp. 49, 103. 
'affected' by Spain and 'our English Espagniolized traitours' that her inclinations once put England itself in danger. She might have been a Scottish Queen, but it was still an English problem. 'I am sure all England had like to haue tasted by so lamentable an experience'. ${ }^{89}$ Meanwhile, one of his most trenchant criticisms of Persons is precisely that he is lacking in the love proper to his national being, or as he puts it more strongly, he is 'degenerate from the honest affection of a true Englishman'..$^{90}$ Hispanicisation was an accusation that easily stuck: it was in just such a way that William Barlow would denounce the same man somewhat later, calling him 'an Hispanized Camelion, [...] filius terrae, no true Englishman either in heart or by birth'. ${ }^{91}$ This is the language of complete alienation: Jesuitism has deprived Persons of national dispositions and even his very birthright.

For those who wanted to construct Englishness to exclude Roman Catholicism, there was always going to be a problem: however much they might have wanted to distance it, there were still English Papists numerically insignificant perhaps, but in terms of their presence in court and their allies on the continent, it was felt, disproportionately influential. It was one of Hastings' great successes that he worked through this particular problem by insisting on the distinction between English birth and having an English heart. His point was that the latter did not necessarily follow on from the former, and that Papists provided the most disturbing example of such a disjunction. The identity of the body was a given, and therefore there was no particular credit or moral value attached to it. His conclusion appears to be that English birth was not enough to be considered truly English. Englishness involves particular allegiances. The orientation of the heart was decisive in fixing identity, and that could only be the result of a mature choice. In the Apologie, he wished that the two would coalesce, 'as they are home-borne, so they may be home-hearted', soundly English, as he went on to say, not just so in a superficial sense. ${ }^{92}$ Targeting his adversary, he imputed to him an ambiguous duality, of carrying a 'Spanish heart in an English bodie'. ${ }^{93}$ He went even further in his judgements on would-be assassins of Elizabeth, casting in doubt the very circumstances of their birth, calling them 'our bastarde countreymen', and again 'bastard born, English'. ${ }^{94}$ The motif of the natural and unnatural

\footnotetext{
89 Hastings 1600, p. 86.

90 Hastings 1600 , sig. $\mathrm{B1}^{\mathrm{r}}$.

91 Barlow 16o9, p. 3.

92 Hastings 1600 , Preface. Unpaginated.

93 Hastings 1600, p. 196.

94 Hastings 1598, p. 49; Hastings 16oo, Preface. Unpaginated.
} 
is also present in Sutcliffe who calls Persons a 'bastardly English renegate'. Accusations of bastardy were not taken lightly (in Persons' case there was a double-entendre because of the malicious gossip surrounding his origins) and it would be fitting to interpret these insults as moments of intense de-legitimation of politically-active Papists in a national context. ${ }^{95}$

The attempt to create some homogenous criteria for recognising English identity and its opposite, although not as pugnacious as in Hastings' writings, deeply pervades Sutcliffe's three works in this exchange. Supporting his ally in exhorting the 'true English', he decides to weigh into the debate on behalf of the 'well affected'. ${ }^{96} \mathrm{He}$ often phrases his clearest statements about true Englishmen in terms of what they find, or, ought to find - as readers, we are alive to the element of auto-suggestion - intolerable. Speculating on the possibility of the Queen's submission to the Pope, for example, he stated that it could not be endured 'nor yielded unto by any true English man'. ${ }^{97}$ It would be an offence to her, but also - and we recall the subtext of selfhood in Hastings - an offence to themselves. He reinforces this subsequently, professing his repulsion to the very idea of submitting 'our selues unto him'. ${ }^{98}$ A true Englishman will stand up for England.

For they may not thinke that all English men are so base, that ever they will endure $[\ldots]$ the tyrannie of the pope, or the command of strangers. Neither can any true English endure to receiue conditions either from pope or Spaniard, much lesse that they shall have power to dispose of this crowne and gouernment. ${ }^{99}$

This is a strong statement of incompatibility. His term of preference for the false hearted is the 'rinegued', or, when his orthography finally settles in 1604, the 'renegate', a term which brought into full relief the unwelcome reality of religious and political apostasy. ${ }^{100} \mathrm{He}$ does include a more generous caveat about the breadth of the term's application, saying that it is confined to the factious elements among the Papists only and those who aid and receive them. ${ }^{101}$ How do we make sense of this reasonably

95 Hastings 1598, p. 49 sets them against Elizabeth's 'naturally borne subiects'. He calls them a 'vipers brood' and also a 'dangerous breed'. Hastings 1598, pp. 66, 42, 79, Sutcliffe 1604, p. 201.

${ }^{96}$ Hastings $1600 a$, sigs. $\mathrm{ar}^{\mathrm{r}}, \mathrm{a}^{\mathrm{r}}$.

97 [Sutcliffe] 1600a, p. 230.

98 [Sutcliffe] 1600a, p. 231.

99 [Sutcliffe] 1600a, p. 233.

100 [Sutcliffe] 1600a, sigs. A5 $5^{\mathrm{r}}, \mathrm{ar}^{\mathrm{r}}, \mathrm{a} 3^{\mathrm{v}}$, p. 149. Also Sutcliffe 1604 , sig. $\mathrm{A} 3^{\mathrm{r}}$. The renegade is often tied to the idea of the hispaniolized. 160oa, p. 30, sig. azvir ${ }^{r}$.

101 [Sutcliffe] 16ooa, sigs. $\mathrm{a}^{\mathrm{v}} \mathrm{-a} 4^{\mathrm{r}}$. 
generous exception and yet still maintain that the construction of identity is deeply and pervasively anti-popish? First, the allowance he makes for loyalists serves a purpose in that it is an encouragement to Catholics to prove themselves English by abandoning all attempts to reCatholicise the country. Practically speaking, it made no sense to alienate people when one could neutralise them by presenting them with normative ideals of behaviour. Still, as is the case with Hastings, we get the impression that although they do make allowances for loyal Catholics, they often slip into the habit of execrating all Papists and their language often casts into doubt the national standing of the entire group. The more 'Catholic' one is (in terms of international sympathies and missionary drive), the less English: that appears to be the logic. There is a progressive scale of alienation: the Jesuits are at one extreme and the 'loyalists' on the edge, potentially if not actually a danger to national man.

Two other elements are also to be uncovered in Sutcliffe's polemic. Like Hastings, he too uses the idea that there is something defective about the affections of Papists. He seized upon Persons' claim that recusants served the monarch 'with body, goods, and life' and disapprovingly - even damningly - remarked that 'he neither mentioneth the heart, nor the inward affection'. ${ }^{102} \mathrm{He}$ also claimed at one point that the Jesuits are 'all linked in affection with the Spaniard', thus permitting them no national sentiment of their own. ${ }^{103}$ What comes across even more strikingly is his perception of Papists as unfree agents rather than as free actors. He sweepingly depicts all the Spanish and Italians as the Pope's agents, and the Jesuits and the plotters in Elizabeth's day as agents of both Pope and Spain. ${ }^{104}$ And surely he had Persons, among others, on his mind when he asked: 'Will you give credence to those, that are by the Italian and Spaniard hired to speake?'105 He felt that such agents should even be deprived of a creditable voice for they were merely mouthpieces for their masters and not voices in their own right: they did not speak plainly or transparently.

This is a crucial distinction which we touched on in Hastings but which needs to be recovered more thoroughly as it is very much part of the substratum of this way of thinking as well as, of course, bearing strong resemblances to political discourses on liberty as they will emerge in the early

\footnotetext{
102 [Sutcliffe] 1600a, p. 155 .

103 [Sutcliffe] 16oob, p. 110.

104 [Sutcliffe] 1600a, pp. 64, 128. See also [Sutcliffe] 16oob, p. 111.

105 [Sutcliffe] 1600a, p. 128.
} 
Stuart period. The key inferences to be made are the following: if you are an agent of someone else, essentially your will is not your own. It follows that you may act, but only in response to directions from those 'above' you, therefore your obedience is blind (the idea of being in thrall rather than subject is a key one), and your agency irresponsible and corrosive. As a free agent, and all these are 'us true Englishmen', then you are, after a manner of speaking, a person in your own right, acting your own part. The theatrical metaphor lies deep as do ideas about how best to represent oneself, typical early-modern preoccupations. Now it is important to note that, in this way of thinking, the true Englishman, although free, is subject to certain realities (like the monarchy and government), but the motivation comes, as it were, from below, from himself. They seem to regard this sort of subjecthood entirely in keeping with right reason and liberty: the monarch does not impose loyalty upon Englishmen so much as 'we are Englishmen and therefore loyal to the Queen and country'. It is interesting just how much emphasis is laid on the archetypal Englishman in this discourse. He is at the very roots of what constitutes the distinctiveness of the polity. The contrary reasoning can also be drawn syllogistically in the following way. Being a member of the Roman Catholic Church entails a subjection to a foreign power. A true Englishman will of course stand up for England. Therefore no true Englishman can be a Catholic (unless he holds aloof from Rome).

The gauntlet was thus thrown down and Persons, inevitably, did 'speak out' in reply. In 1599, there was A temperate vvard-vvord and in 1602 The Warn word to Sir Francis Hastinges wast word. Persons had his eye on a fullscale reply to Foxe's Actes and Monuments which had been republished in 1596 but this rather more immediate controversy allowed him to make his case in a less scholarly manner. ${ }^{106}$ There are many ways of tackling his replies but our questions centre around whether or not he had an equivalent idiom of his own about nationality and whether he made strategic inroads into their favoured vocabulary so as to re-appropriate it to his own ends? To both we are forced to give a negative reply - albeit a qualified one. It is true that Persons, by then twenty-one years a Jesuit priest, most of which time he had spent abroad, did make some kind of appeal to the fact of his readers being English, but mostly to drum up a sense of unity in the wake of recent divisions and changes: 'we are English-men, and we talke to men of the same language and nation [...], many have seen the change, and knew the state of things [...] before the alteration'. It was

106 Edwards 1995 and Carrafiello 1998 for general biographical details of Persons. 
reinforced by the nostalgic recall of an anterior unity: the Reformation was responsible for all the divisions 'among ourselves'. ${ }^{107}$ Hastings had stressed England's blessings under Elizabeth; Persons, its lamentable failure to secure unity. However, all this was unlikely to win a case in the present. He does not - and it is hard not to see this as an unfortunate omission - convincingly champion the Englishness of the recusants or Jesuits in the fifth and sixth encounter of the VVard-vvord. Being so occupied in the negative case - proving that they were not traitors - meant that the positive case did not stand out sufficiently clearly.

Most illuminating of all are the two intertextual show-downs between Persons, on the one hand and one or both of his opponents on the other. The first concerns the rhetoric of the plain and true English heart which Hastings had been so enthusiastic about exploiting. Persons picked up on this emphasis, found it to be nonsensical and proceeded to rip the idea apart. The phrase that he lit upon was the one where Hastings had asserted that those who were truly English would be incorruptible in their dealings with bewitching recusants and that the 'bare sense of a true English heart' would always be able to distinguish. ${ }^{108}$ Bareness for him carried with it the wholly positively connotations of plainness, integrity and honesty, something that was made even more patent in his Apologie of 1600 when he returned to the idea, clarifying it still further by linking it firmly to the law of nature; his point being that even without the benefits of Divine or civil law, 'it is such a heart, as hauing onely the light of nature [...] would not so brutishly seeke the life of their lawfull Soueraigne, to the betraying of their countrie into the handes of straungers'. ${ }^{109}$ Persons reveals the workings of his mind when he simply refuses to fight on these grounds, for, as he said, 'we do measure the matter by an other balance, then by the sense of so bare an English heart'.10 This moment in the exchange reveals just how different these two are in the orientation of their ideas. For the knight, as we have seen, the logic of the simple English heart was utterly fundamental; for Persons not so. It is an egregious basis for any argument.

Persons then proceeded to deconstruct and ridicule what his opponent may have meant by this 'measure' of Englishness. If in its original state, the heart praised by the other was, he contends with some asperity, not Christian at all, but a 'hard heathenish' one. Nor does the fact that it is

107 [Persons] 1599, p. 3.

108 Hastings 1598 , p. 86.

109 Hastings 1598, p. 171.

110 [Persons] 1599, p. 82. His sixth encounter deals with the case of recusants. 
English add to its credit, because 'if you do adde the English cut', it is even worse than in the state of nature, considering how 'hartes go there for the most parte among protestantes at this day'. To add a 'cut' is somewhat oxymoronic but appropriate. What Persons probably means is that the Reformation has added what was not there before, and taken away what was. Besides, he goes on blisteringly, the fact of one's heart being confined to English sympathies showed petty-mindedness and abject servility in the extreme.

[I]f it be so truly and barely English, as it hath seen no other countries, nor knowen other paradice then English earth, nor thought of other blisse then with you is commonly treated, and that it be as servilly tyed to oxen, and steeres, and other temporal base commodities, as your soule sheweth itself to be. ${ }^{111}$

Neither Persons' God nor his world-view was especially English. He has no sensitive national consciousness about these matters and is blistering about any attempt to construct such. As a well-travelled man (having lived in Prague, Rome, Padua, Venice, Paris, and Spain), he mocks the narrow parochialism that Hastings' 'measure' implied. His vision was so narrow that he could envisage no other paradise than an 'English earth'. There is a critique of uncouth ruralism in the passage - Hastings' family were landowners - and a scathing disdain for the idea of a national utopia, wedded to base things like cows and commodities. We also note that he tries to turn the accusation of servility against his opponent. Hastings' 'bareness' is Persons' 'baseness'; his freedom is the other's boorishness; his prosperity is the other's parochialism.

Persons does not stop there. Relentlessly, he moved on to exploit the theological resonances of the comment, taking issue with the description of 'bareness' as something positive, because all it brought to mind was 'your English sole faith [sola fides] and bare belief. The 'your' English distanced himself somewhat: he seemed to take positive pride in not having a narrow English heart - nationally, culturally, and theologically. Fundamentally, he was insinuating that the heart described and endorsed by Hastings was incapable of displaying or, for that matter, recognising goodness or greatness, being merely tied to its antipathies, - or as Persons spelt them out here - 'to the contempt and hatred of all good woorkes', and 'to resist the bewitching of recusants good life [... and of] Christ himself'. ${ }^{112}$ Persons shows himself quite the controversialist, with plenty of

\footnotetext{
111 [Persons] 1599, p. 81.

112 [Persons] 1599, pp. 81-82.
} 
stomach for a good fight. It is an unambiguously combative response to a discourse based around a particular vision of national identity and is relevant for us because it shows that not every polemicist was persuaded by the easily-used, easily-accessible emotionally-charged idiom about what Englishmen ought to do qua Englishmen and how they ought to feel. Yet, strategically, although his mockery is refreshingly iconoclastic, it may have been ill-timed. If the only time he met his opponent on his own terms was to scoff at them, then this did not give him a chance to play the loyalist card.

The other striking instance of complete divergence on this subject occurs in the traditional staging of national enemies in the work of the Protestant controversialists and Persons' refusal to do anything of the sort. With Hastings and Sutcliffe, it is as we would expect: foreigners, especially the Spaniards, are type-cast as the villains. In the opening image of A vvatch-word, Hastings conjured up a vivid image of the 'raging hearts' of Rome and Spain as if the very places could be personified in their antipathy to England. ${ }^{113}$ If Hastings does make clear distinctions between the influence of the two, it is along the lines that the latter was the political arm of the former and consequently, to his mind, more of an immediate threat. Sutcliffe is more careful in his distinctions in this regard: for him, there is a definite hierarchy of danger: the Spanish are enemies but on the bottom rung, the Pope and his agents are worse, while the recusants are the worst of all. ${ }^{114}$ In any case, it is principally in Hastings' work that we locate an entire 'argument' - if it can be called such - built upon the depiction of the national character of the 'Spaniard' very much in the style of the black legend. It is also significant because it attracts the attention of Persons, whose links with Spain were profound and who, on the head of it, launched a devastating critique of the idea of national typology in his eighth encounter. ${ }^{115}$

Hastings claimed that the natural bent of the Spaniard lay in ambition and treachery, and that, backed by Rome and Romanists, they would not rest until England was enslaved. ${ }^{116} \mathrm{He}$ is the 'proude tyrannical Spaniard' of the leyenda negra, the endlessly repeated characterisation of sixteenthand early seventeenth-century polemics. What would happen once, or what would have happened if the 'rauening' creature - and the beast-like adjective is deliberate - did 'catch hold on vs' called forth some of his

113 Hastings 1598, p. 3 .

114 [Sutcliffe] 1600a, p. 148.

115 [Persons] 1599, pp. 102-113.

116 Hastings 1598, p. 53. 
grittiest speculation. The Englishman's womenfolk would be deflowered: the connection between national seduction and physical defilement, while not explicit here, is to be inferred; his sons, the future of the country would be subjected to slavery, while he himself would either face a lingring tormenting life, or a bloody cruell death'.117 In either case, a disaster. If Philip had got his way in the 1550 s, legal deformation would have followed physical degradation, with common law giving way to an inquisition. Hastings' lurid depiction was the standard vision by then but it was no less compelling, serving both as a sharp warning and a reminder to the true freedom-loving national man to count his blessings.

For Persons, this lazy stereotyping is utterly nonsensical and he devoted the whole of his eighth and final encounter to rebutting these claims thoroughly. He does have something new to say here, something different: the strongest explicit statement to be found in the polemical literature of the period against the whole notion of national character and national stereotyping. In that, he appears more modern than so many of his contemporaries: the simple moral geography which stated that the Spanish were tyrannical, the Italians crafty, the Flemish drunks, the French flighty, he thinks entirely vacuous. There is something impressively free about the way he ridicules the idea that there are such things as generic national characterisations, asserting that in every nation there were in fact 'all sortes'. ${ }^{18}$ Cutting through swathes of invective and fallacy, he argues forcefully that there are no national types, merely individuals, and that it would be as ridiculous to depict all Spaniards in terms of 'the Spaniard', as to judge Englishmen on the basis of a few unrepresentative examples. The passage is worth quoting in full.

$[\mathrm{W}]$ hat reason is there [...] that these defectes should be attributed vniversally to the whole Spanish nation, wherin there are to be found thousands that haue no part nor fault, as on the other syde, if some English-men as they passe ouer other countries, by sea and land at this daye should behaue themselves scandalously, by gluttonie and drunkenness (as diuers haue byn said to do) is it a lawfull consequence to say or think, that all English are such at home, and that these are the qualities of the English nation, as Sir Francis sayth here of the Spaniardes? ${ }^{\text {?19 }}$

The disreputable English travellers that satirists loved to hate: were they representative of the nation at large? Persons' answer is a resounding

\footnotetext{
117 Hastings 1598, pp. 86-88.

118 [Persons] 1599, p. 105.

119 [Persons] 1599, p. 105. My italics.
} 
negative. Enjoying the rout he was making, he continued slyly that supposing there was a situation in which a particular English knight produced a book full of lies and calumnies, it would not be at all fair if foreigners judged all English knights to be so 'fond and frantik'. The implication lay open and wounding that Sir Francis was not the typical Englishman anymore than he was the typical knight. ${ }^{120}$ The nation was a sum of its individuals not a collectivity of 'types'. Persons was also bold to assert the positive in England's past relationship to Spain and to point out that it was not merely - or even primarily the Spaniards who hated the English but the English who had mistread and misinterpreted the Spaniard. Moreover, he accounted for anti-Spanish prejudice not only in terms of anti-Catholicism, but also in terms of sheer envy at their success, something that his opponents would have been loathe to admit, but which, given Spanish greatness on the world stage, was a fair judgement. ${ }^{121}$

In sum, what we have here is an extremely strong statement of an antiessentialist position on national identity. Persons' scheme of things did not allow for the moral judgements of nations which was an habitual fallback position for a certain type of early-modern commentator. For him, there was no such thing as a pure and unadulterated epitome of national being and consequently, attempts to generalise about this matter deserved only derision. There was no set canon of foreign villains. This was certainly the more intellectually sophisticated point of view; but the battle for minds and hearts is not necessarily won by the better argument. Saying so did not chime at all well with the polemic of the age which throve on a diet of anthropological Manichaeanism. Given his position, he could perhaps do no less, but one cannot help feeling once again that although technically successful in shredding his adversary's argument on this point, he was strategically less than canny. There was intellectual merit in his critique but his very warmth in coming to the defence of a national enemy was hardly likely to recommend him to English readers of a certain variety. And, of course, whatever he said would be seen through the lens of his reputation as the most un-English of Englishmen. The very subtlety of his approach would count against him because subtlety was just one of those qualities which plain people abhorred. Hastings was surely not alone in attributing such counter-cultural opinions to the habitual Jesuit addiction to Spain. ${ }^{122}$

120 [Persons] 1599, p. 105.

121 [Persons] 1599, p. 104.

122 [Persons] 1599, pp. 104-110; Hastings 16oo, p. 162. 
Hastings hardly modified his views on the matter when counterattacking. ${ }^{123}$ There was one small concession, it is true, so small that it is in danger of being overlooked, when he acknowledged the existence of a remnant of Spaniards who did not have the typical disposition. Nevertheless, and he struck out again, the bloody, tyrannous, ravening and voluptuous 'humours are in the generalitie of them'.124 Apart from this small allowance, he showed, if possible, more vehemence in depicting the innate 'cautele [cunning] of the Spaniards nature' in 1600 than he had two years previously, brandishing examples which bolstered his monolithic schema. ${ }^{125}$ His purpose here was still exhortative, 'to put our men in mind of the Spaniards humours'. ${ }^{26}$ As before, he was much given to speculation on what would have happened had England taken a different course, through, for instance, Elizabeth's marriage into Spain. In that case, he had no hesitation in saying that it would have led 'to the killing of all true English hearts'. ${ }^{127}$ Sutcliffe was somewhat more even-handed. Perhaps he was a little embarrassed by his co-religionist's generic judgements; in any case, he made greater concessions, and gave a more balanced picture of Anglo-Spanish dealings in the past than Hastings was capable of doing. ${ }^{128}$ Still from the Protestant side, a very simplified vision emerged: there was a great comfort in pawning traditional stereotypes and indulging in the pantomime play between the good English and the villainous other.

By 1604 this particular episode had either spun itself out, or perhaps, considering the internal evidence, it is better to speak of it as having been cut short. In 1602, Persons had made it clear that he envisaged a whole series of refutations to the claims made by the Knight: of the eight 'encounters' or points of debate, which he highlighted in 1599, he now focused on the first two alone. He never got around to completing the rest systematically, perhaps because the events of 1605 overtook him and made answering another kind of question more urgent. Persons, despite or perhaps because of his skills as a controversialist, did not meet them on their level to any great degree, considering it, as he made clear, too petty and parochial. Thus it came about that he only addressed the narrowly polemical questions but failed to make the emotive case, assuage their fears of the

123 Hastings 16oo, pp. 194-215.

124 Hastings 1600, p. 197.

125 Hastings 1600, p. 197.

126 Hastings 1600 , p. 196.

127 Hastings 1600, p. 205.

128 [Sutcliffe] 1600a, pp. 205, 189-192. 
enemy within or convince readers that English Papists were as truly and really English as their Protestant brethren. Furthermore, instead of capturing and colonising the language of his opponents, he merely ridiculed it, thereby missing the opportunity of re-appropriating the rhetoric of Englishness that the others had so thoroughly cornered. The ultimate irony of the exchange thus may be that Robert Persons, who was so often vilified on all sides for being the archetype of the 'politique' Jesuit, showed himself here to be not 'politique' enough. 